\title{
Article \\ Dowry, the Oppression of Women and Femicide in Bangladesh
}

by

Mohammad Sadikur Rahman, PhD

Leader: Foundation for Women and Child Assistance (FWCA), Rajshahi

Leader: Research Unit, Bangladesh Law Times (BLT), Dhaka

Bangladesh

+880 1715032439

sadikfwca@gmail.com

Keywords:

dowry, oppression of women, femicide, Bangladesh

\section{(c) (†) (?)}

This work is licensed under a Creative Commons Attribution-ShareAlike 4.0 International License. 


\section{Abstract}

The marriage transaction, commonly known as dowry, is a widespread phenomenon in Bangladesh, which has inevitably attracted much attention from social science researchers. This has transformed bride wealth marriages to dowry marriages in Bangladeshi society. A dowry is what the groom's side demands in cash and kind from the bride's side to complete the marriage. It is a major cause of women's oppression, which starts from diversified psychological and physical torture that may finally end into femicide. The main objective of this paper is to analyse women's oppression in relation to the dowry practice as a social problem in Bangladesh. This paper also explains the various dimensions of this problem, its multiple functions in women's oppression, the nature of oppression in its various stages before femicide and the nature of femicide. The paper draws on secondary data from Bangladesh. It is observed that women in Bangladesh are physically, psychologically and socially oppressed by their husband and his family members in many ways because of the dowry. The nature of oppression is diverse in form, but ultimately these oppressions turn into femicide. The nature of femicide is also diverse, and some fire-related deaths and the suicides of young married women are also believed to be related to dowry.

\section{Keywords}

dowry, oppression of women, femicide, Bangladesh

\section{INTRODUCTION}

The oppression of women is a global problem and concern for achieving equality, development and peace. In many societies to a greater or lesser degree, women are oppressed, which cuts across lines of income, class and culture. Bangladesh is no exception and the oppression of women is a widespread social problem across the country. The patriarchal nature of society, the stratified social system, the peripheral capitalistic form of the social structure and religious norms are intricately functioning in favour of male domination, where the marginalization of women is continuing in Bangladesh (Rahman \& Khanam, 2008). This creates a sociocultural environment where the oppression of women occurs. Being in a patriarchal society under a capitalist system, the subordinate and marginal position of women is associated with women's lives, in which they are dominated and subjugated by men. The subordinate positions 
of women allow men to dominate and control not only their families and resources (Schuler et al., 1998 stated in Hossain, 2007), but also the lives of women in Bangladesh. In Bangladeshi society, women face various forms of oppression, ranging from spousal abuse to rape, dowry killing, acid throwing, sexual harassment and sexual slavery through the trafficking of women (Zaman, 1999), among which domestic oppression is widely prevalent as an everyday matter in women's lives. Dowry has mostly caused the domestic oppression against women in Bangladesh. Societal norms and traditional values associated with gender roles and the supremacy of males within households and society tend to trigger, dictate and provoke domestic oppression against women in Bangladesh. This system indicates the superiority of the man, and is a way to establish patriarchal norms. In Bangladeshi society, most of the oppression caused against women is due to the non-payment or inadequate payment of the dowry (Jahan, 1994), especially domestic oppression. Dowry-related oppression has been proven to be highly complicated in Bangladesh, and it is because of dowry-related oppression that many women have been killed and others subjected to physical and mental oppression (Kamruzzaman \& Aziz, 2009). The report of violence against women survey from 2011 identified that as many as $87 \%$ of currently married women have experienced some type of violence by their current husband (BBS, 2013). This report stated that approximately one-third of women (33.7\%) have paid a dowry in their current marriage (BBS, 2013). It is proven in Bangladesh that a dowry is a major cause of women's oppression, which starts from diversified psychological and physical torture, and finally turns into death (dowry killing or murder, or dowry death), and which international organizations (WHO, 2012; ACUNS, 2013) and researchers called femicide. The main objective of this paper is to analyse the oppression of women and femicide because of the customary dowry practice in Bangladesh. This paper also explains the various dimensions of this problem, its multiple functions in women's oppression, the nature of oppression in the various stages before femicide and the nature of femicide.

\section{METHODOLOGY}

The paper draws on secondary data from Bangladesh, and relies on the quality of these data sources, which is crucial for the validity of gaining knowledge and the method. In general, quantitative data and information on the dowry deaths of women are scarce and not well documented. One obstacle refers to the legal process in 
proving a dowry death before the verdict comes from the court. However, the human rights organizations in Bangladesh are collecting data on dowry deaths from national newspapers in their effort to document this atrocity. Among these, both Ain o Salish Kendra - ASK (a legal aid and human rights organization in Bangladesh) and Odhikar (a human rights organization in Bangladesh) are pioneers. I use their collected data to illustrate the frequency of dowry deaths for Bangladeshi women in different age groups categorized as 'killed' or 'suicide' (Table 1 below) and dowry deaths for different age groups compared to cases filed (Table 2 below). The available data have been reorganized for the purpose of this article, as well as to reflect the process of reasoning, although the set-up of the categories fully rests on the secondary data from the two sources.

\section{CONCEPTUAL MEANING AND NATURE OF DOWRY}

Generally speaking, dowry means the transmission of large sums of money, jewelry, cash and others goods from the bride's family to the groom's family (Srinivas, 1984). It refers to property, cash or goods given to the bridegroom as a consideration of marriage (Begum, 2014). But the extended meaning of a dowry according to Bangladeshi law related to dowry includes anything exchange in the consideration of marriage. The Dowry Prohibition (Amendment) Ordinance of 1984 extended the definition of dowry to 'any property or valuable security given and agreed to be given either directly or indirectly by one party to marriage by another party at any time before or after the marriage as a consideration of marriage'. Nowadays, a dowry takes the form of inducement for a man to marry a woman. In contemporary Bangladesh society, 'There is a common tendency to consider a dowry as the groom's price. It is differentiated from kanyadan or the bride's wealth. At present the bride's family sends large sums of money, jewelry, cash and others goods to the groom's family' (Taher, Islam, Chowdhury, \& Siddiqua, 2014). It also includes home, job placement for grooms, land or business, and so many other things. The contemporary concept of dowry in no way resembles the original concept of dowry. Over time, what was voluntary has become obligatory, an essential part of marriage recovered through the coercion of brides (Chowdhury, 2010). 'The miseries of the bride's parents do not end with their giving a dowry at the time of marriage. The customary practices demand a perennial flow of gifts from the parents of the girl to the boy's family on all festivals' (Ibid, 2014). It states that even if there is a need to face economic hardship or even to run for a loan 
to meet the expectations of the groom's family, they would do it (Monsoor, 2003). Ameen writes, 'In several cases, they (the bride's family) continue to fulfill the demands of their daughter's in-laws, forgetting that a woman cannot buy peace, not to speak of affection, by meeting the monetary demands of her in-laws. The demands may lead to constant nagging and bullying, which is even more damaging to the human spirit. Sometime, dowries are demanded after the wedding ceremony. The refusal to pay could result in the daughter being divorced, or even oppression causing the death of the bride' (Ameen, 1997).

\section{BRIDEWEALTH TO DOWRY MARRIAGE IN BANGLADESH}

The contemporary customary practice of dowry is a fairly new phenomenon in Bangladesh (Geirbo \& Imam, 2006). Before the spread of dowry marriage, bridewealth marriage was the common practice in Bangladesh society (Ibid). Bridewealth refers to marriage transactions that go from the groom's side to the bride's side in connection with the wedding (Ibid). This transaction is not the same as Mahr; instead, it refers to something else from the groom's side. For Bangladeshi Muslims, Mahr is religiously sanctioned, though a dowry is not supported by state or personal laws. Mahr is an essential part of a Muslim marriage in Bangladesh. Islamic law does not specify any maximum amount of Mahr, but makes it obligatory for a husband to pay whatever amount has been fixed, and whatever amount is assessed if not fixed (Monsoor, 2008). Mahr is paid by the husband to his wife out of honour and respect, and to show that he seriously desires to marry her with a sense of responsibility and obligation (Monsoor, 2003). Hence, Mahr is not similar to dowry practices. It is to be noted that the Dan (gifts), which has been practiced for a long time on a voluntary basis, also differs from contemporary dowry practices in Bangladesh. During the dominance of bridewealth marriage, the voluntary gifts (Dan) from both the bride and groom's sides have been done by relatives and family friends, but in a dowry marriage the transactions are settled through a bargaining system that is not voluntary; rather, these are obligatory for the bride's side. As a result, contemporary dowry practices are popularly called 'demand', while a dowry marriage is called a 'demand marriage'.

Even though a number of researchers have attempted to prove that dowry marriage has been in practice since ancient times (Kamruzzaman, 2015), most state that the dowry marriage system has primarily emerged in the Hindu community, and that the 
most ancient institution of marriage in the Vedic period was associated with 'Kanyadhana', which were gifts (Dan) to the virgin bride; 'Varadakshina' and 'Stridhana' were voluntary gifts given by the bride's father to the groom, as well as voluntary gifts given by the relatives and others, respectively, to the bride (Kamruzzaman, 2015). In total, these were contributions to the groom and his family from the bride's side, and these were very much voluntary. The most popular type of marriage was bridewealth marriage, and the voluntary gifts from both sides took place because of a sense of helping or encouraging the new couple in their new life. As a result, that there is no connection of dowry with the voluntary gifts of bridewealth marriage we call Dan (gifts). In fact it seems that the dowry system as it is practiced today was unknown in the early period (Nithya, 2013). This unknown and willing practice of the ancient period, which was mostly prevalent in wealthier families, has unfortunately now been transformed into the greed of the dowry system, which is a blow to most ordinary families, and has become an open secret demand for marriages; thus, a dowry is an accepted social custom in Bangladeshi society (Kamruzzaman, 2015).

The contemporary dowry practice among upper-caste Hindus of Bengal first started to escalate at the dawn of the 20th century, as they sought English-educated men in government service as bridegrooms for their daughters (Risley, 1915). This practice then spread to other castes in Bengal (Sharma, 1980). However, In Bangladesh (known previously as East Bengal), a Muslim-dominated area, the prevalence of dowries began to increase in the 1960s (Lindenbaum, 1981), becoming an alarming social problem during the 1980s. Hence, the state passed an anti-dowry law as a result of the social movement by social activists, especially female activists. The dowry practiced nowadays in Bangladesh is also known as a groom-price, and is a marital payment to the groom's family. The groom-price, or price dowry, emerged in India beginning in the late 19th century (Srinivas, 1984; Banerjee, 1999). In Bangladesh, dowry is a more recent phenomenon, dating back to the 1940s (Lindenbaum, 1981; Hartmann \& Boyce, 1983), and is the replacement of bridewealth marriage.

\section{THEORIES OF DOWRY}

There is a large growing amount of literature in the social sciences on the customary practices of dowry in Bangladesh, and a considerable debate about what constitutes dowry in its contemporary forms in this society. Scholars and researchers are divided 
on explaining this, with a number of theories developed regarding the dowry practice in both a regional context and Bangladesh. To acquire a better understanding about dowry practice, the reasons for its emergence and multi-dimensional functioning, there needs to be a discussion of the theories of dowry that the researchers attempted to explain. The following brief discussion will therefore be helpful in understand the problem more clearly.

\subsection{MARRIAGE SQUEEZE AND FEMALE COMPETITION}

The first cited explanations for the rise of dowry is the 'marriage squeeze' theory introduced by Caldwell, Reddy and Caldwell (1983).'The key to understanding this theory is the demographic effects of declining mortality in a population in which men marry women from younger cohorts than their own. As mortality falls, younger cohorts will increase relative to older cohorts, leading to a surplus of marriageable females. Thus, the forces of supply and demand will result in a switch from bride price to dowry' (Suran, Amin, Huq, \& Chowdury, 2004). In fact, this theory argues that dowry occurs when there are more women than men in the marriage market, and that bridewealth occurs when the situation is opposite (Geirbo \& Imam, 2006). Rao (1993), Bhat and Halli (1999) and Amin and Cain (1997) support the theory that the marriage squeeze was a major factor in the change from bride price to dowry in India and Bangladesh. Lindenbaum pointed out that the switch from bride price to dowry in Bangladesh is not necessarily a result of the shortage of men, but rather an increased competition for high-quality grooms (Lindenbaum, 1981). In other words, instead of the female competition model of dowry, a more correct term for dowry would be groom-price, which reflects the fact that marrying into a wealthier family can 'buy' a bride and her family's higher social or economic status. For example, in Bangladesh a dowry increases in tandem with the age at marriage, thereby placing pressure on parents to marry their daughters early. This may be particularly true if the bride suffers from other disadvantages in the marriage market, such as a lower social status or darker skin tone (Suran, Amin, Huq, \& Chowdury, 2004). But while the marriage squeeze can explain the switch from bride price to dowry, it cannot explain why dowry inflation has persisted despite an equalization of cohort sizes in Bangladesh. Even though demographic projections have pointed to an easing of the marriage squeeze (Bhat \& Halli, 1999; Amin \& Cain, 1997), high dowry payments have persisted. Geirbo and Imam's (2006) statement is more important as they wrote, '.... in societies where there is no significant 
disproportion between men and women, like in Bangladesh, this theory can provide an explanation for the practice of dowry. If people believe that there are more women than men on the marriage market, they will act correspondingly to this belief. Social and cultural ideas about men, women and marriage are also significant for creating an imbalance between marriageable men and women. In Bangladesh, the socially accepted marriage age for a woman is lower than for a man. As the norm is that a man should marry a woman who is several years younger than him, this creates a tighter marriage market for women than men'. The age of marriage, especially for women, is an alarming factor that must be counted in the inflation of dowry practice in Bangladesh, along with other factors like social status, the colour of girls and other disadvantages for girls in the contemporary marriage market.

\subsection{DOWRY AS BEQUEST AND WELL-BEING FOR THE BRIDE}

This theory cites that a dowry actually benefits brides by acting as a form of a premortem inheritance that supports a bride's marital welfare (Naved \& Persson, 2010). Following this theory, although sons obtain their inheritance on the death of the parents, daughters receive their share when they marry (Edlund, 2001 cited from Naved \& Persson, 2010). The notion of this theory is supported in China's society, which many studies have attempted to prove. Scholars who are supporting this theory concluded that a dowry has a positive effect on a wife's bargaining position, as well as her self-reported life satisfaction (Brown, 2002). But a number of scholars have given their opinion against the notion of this theory, and the main thing that they raise is the control over resources after marriage and during divorce. They stated that 'unlike in China, where brides control their dowry even in the event of divorce, in Bangladesh and other South Asian countries the dowry constitutes what is demanded by the groom's family rather than the share of parental property to which a daughter is entitled' (Amin, Selim, \& Waiz, 2006). 'Dowry payment in India, Pakistan and Bangladesh consists of wealth transferred to the groom and his parents from the bride's parents; the bride has no ownership rights over the payment' (Naved \& Persson, 2010). The positive side of dowry, what the bequest theory cited, has been variously criticized by scholars. The well-being of the bride (because of the dowry payment) that this theory tried to explain has also been criticized by the scholars. Although some of the scholars tried to link dowry with the ancient Indian concept of stridhan, the contemporary practice of dowry in Bangladesh is totally different from these. The notion under this 
theory about the ownership of dowry may lead to wrong conclusions (Naved \& Persson, 2010); this is despite the fact that there are some implications in Bangladesh that the higher the amount of the dowry paid at marriage, the more difficult it is for the husband to divorce, as well as the bride possibly getting some advantages in the groom's family. Nevertheless, in the Muslim divorce system, the husband only has to return his wife the mahr, and is not obligated to return the dowry payment. The studies conducted in Bangladesh show that dowry does not necessarily benefit brides in Bangladesh (Amin \& Suran, 2005). The studies demonstrated that women who pay a dowry report more domestic work, less leisure time and spend less time on self-care activities (Naved \& Persson, 2010). But the dowry practice in Bangladesh continues because of the hope for security, attaining honour and preventing the divorce of the bride. These hopes of the parents of the bride are common thoughts influencing factors for the inflation of the dowry.

\subsection{COLONIALISM AND ECONOMIC LIBERALIZATION}

The contemporary practice of dowry in Bangladesh (Bengal) has to be seen as a product of colonial rule. The British administration in Bengal created individual male ownership of the land, so that males became the dominant legal subjects. The masculinization of the economy and the recruitment to the government services in Bengal made sons more desirable than daughters (Oldenburg, 2002). During the colonial period, the works in the civil or military bureaucracy were the source of cash and land rewards. Before that, the English-educated middle class were coming to the forefront in Bengal with job placement by the colonial ruler, which escalated dowry practices among the higher class during the 20th century . For this reason, the families of grooms with access to such jobs started to demand dowries from the brides' families. The parents of potential brides knew that a good dowry was the way to secure the best groom, hence contributing to the dowry practice (Ibid). This socioeconomic theory of the development of the dowry practice was undertaken by many other researchers. They tried to point out that the period of escalating dowry violence in Bengal coincides with the process of economic liberalization, the growth of the middle class and increased consumption (Siddiqi, 2002). The post-independence period in Bangladesh has been a period of increased social differentiation and new possibilities for capital accumulation, in which dowry has become a tool for social mobility within this socioeconomic environment (Siddiqi, 2002). On the other hand, researchers also point 
out that the economic modernization, particularly in the agricultural sector, saw women as an economic burden in their household, insofar as they were not involved in traditional rice production in Bangladesh, which contributed to an increase in dowry marriage. They also write that although the shifting of bridewealth to dowry marriage has economic reasons, it was the ideologies of purity and honour that sustained the practice in Bangladesh society (Rozario, 2001). At the same time, the overall economic system of Bangladesh became increasingly capitalist, and so the system of prestige changed from the aristocratic values to the accumulation of money. In contrast, the educated and urban employed men became largely available, and the parents of the grooms started to demand dowries as reimbursement for an investment in their son (Ibid). Researchers explain that the decrease in the economic role of women is accountable for the dowry practice in the sub-continent (Kishwar, 1999). But White (1992) challenges the notion of economic modernization theory, arguing that at the same time as dowry increases, the rate of women in paid labour also increases (White, 1992). Moreover, he noticed that rice husking is no longer an important source for females to earn money, as the garment industry has opened up a new and large arena for female employment. White indicated that it is not the economic role of women, but rather the social construction of them as dependents that inspires the dowry practice (White, 1992). It is stated that, 'If there is a social construction of women as dependents, increasing employment opportunities for women can occur in parallel with dowry inflation' (Geirbo \& Imam, 2006).

\section{THE OPPRESSION OF WOMEN AND DOWRY IN BANGLADESH}

In Bangladesh, dowry causes the abuse of women, murder and many other types of violence, while also encouraging underage marriage, polygamy, etc. (Huda, 2006). From the beginning of the 1970s up to the present day, dowry demands are cited as a major cause of female oppression (Taher, Islam, Chowdhury, \& Siddiqua, 2014). From 1980-1982, dowry was allegedly the major cause of suicide nationwide (Jahan, 1994). A report showed that in the Jhenidhah district, the majority of suicides reported during 1991-1995 were attributed to dowry demands (Taher, Islam, Chowdhury, \& Siddiqua, 2014). The non-payment or inadequate payment of dowry is a common cause for the harassment of women and divorce (Agarwal, 1994). The demand for dowry underscores most forms of psychological torture within marriage, in particular the threat of divorce (Roy, 1992). The demands often continue after marriage, with the wife 
suffering physical and psychological torture for the inability of her parents to fulfill additional and ongoing demands. This may cause the marriage to end in divorce or for the husband to marry again in order to procure more dowries (Taher, Islam, Chowdhury, \& Siddiqua, 2014). The nature of oppression because of dowry is varied, starting from psychological to physical, or both physical and psychological together. On the other hand, the economic and social impact of such violence is tremendous and is not always reported, but nonetheless happens in cases of dowry-related oppression in Bangladesh. The violence may start from criticism by the husband and in-laws or other members of the groom's family, including neglect of the wife, psychological torture (sexual and other issues), thereby hurting the self-esteem of the wives, ill treatment (sending her to her parents' home or marrying another woman), restriction on movement, beatings, etc. In addition to both physical and psychological torture that may lead to the killing of the woman, kitchen burning and fire-related deaths, as well as the suicide of young married women, are also believed to be related to dowry killings. The various forms of violence against women because of dowry payments prove a positive association between dowries and violence (Naved \& Persson, 2010).

Psychological oppression: Psychological or emotional oppression may start just before the marriage and continue after marriage. Before the marriage of a woman or girl, the bargaining matter of dowry itself a psychological oppression for a girl or woman, or even for the parents of a bride. At this time, the marriage may be stopped or not fixed due to the settlement of a dowry, sometime hampering the prestige of the bride and her family. However, the acts of psychological or emotional oppression might be more devastating than the physical or other types of oppression (Johnston \& Naved, 2008). Psychological or emotional oppression against married women is common and persistently practiced by the husbands and the members of the in-laws family in Bangladesh (BBS, 2013). A report in 2001 shows that $44 \%$ of urban women and $31 \%$ of rural women in Bangladesh have experienced psychological or emotional oppression - defined as including insults, humiliation, intimidation and threats-with $29 \%$ of urban women and $20 \%$ of rural women reporting having experienced emotional violence in the past year of this report (Johnston \& Naved, 2008). The Violence against Women Survey in 2011 shows that approximately 80\% of married women have experienced psychological violence in their lifetime, with the prevalence seeming 
slightly higher in rural than urban areas (BBS, 2013). The issue of emotional or psychological oppression in connection with dowry practice is complex, and data is scarce in Bangladesh, but it is very common and mostly happens at the domestic level. This oppression may start at the very beginning of the married life of a bride because of an inadequate dowry or the demands of more dowry.

Sexual oppression: The data on sexual oppression against married women in Bangladesh is still scarce. This is not documented because there is no legislation against criminalized sexual oppression within a marriage in Bangladesh, even though forced sex, or rape, within a marriage is prevalent, particularly among very young couples (Johnston \& Naved, 2008). Very few studies have investigated sexual violence against married women in Bangladesh. In 2001, a WHO study revealed that approximately $37 \%$ of women in urban study areas, and $50 \%$ of women in rural study areas, reported having been sexually violated by their husband (Ibid). Johnston and Naved (2008) wrote that $24 \%$ of urban women and $30 \%$ of rural women reported that their first sexual experience was forced. Women aged less than 15 years at the time of their first sexual encounter were more than twice as likely to have forced sex compared to women who were over the age of 18 years at their first sexual encounter. The Violence against Women Survey in 2011 shows that approximately $36.5 \%$ of women experienced sexual violence perpetrated by their current husbands in their lifetime, with sexual coercion as a result of physical force or fear of consequences being the most common sexual violence experienced by married women (BBS, 2013). This report also cites that as many as 30\% of women had sex with their husbands because they were afraid of what the husbands might do if they refused. Underage marriage is still an alarming issue in Bangladesh, where dowry payments are also an influencing factor. Hence, underage brides face sexual violence at the beginning of their spousal life.

Physical oppression: Physical oppression against women in Bangladesh comprises a range of physically violent acts, including hits, slaps, kicks, beatings, burns and beating by use of objects. However, because violence in Bangladesh is commonly perpetrated specifically by a woman's partner, i.e., the husband, and often in the home, it is often considered as a 'private issue' - and thus not a matter to discuss, research or act on (UNECE, 2010). Many studies have tried to measure the rates of physical 
oppression of married women in rural Bangladesh in the decade from 1992-2002. A study found that approximately $47 \%$ of women of lower socio-economic status in the six villages in the three districts of Bangladesh reported having experienced physical domestic violence (Johnston \& Naved, 2008). In 1993, 42\% of women in Jessore and Sirajganj reported being beaten by members of their households in the recent past, and approximately $43 \%$ of women in a Gazipur-sampled area reported physical violence in the past year (Ibid). The Violence against Women Survey in 2011 shows that $65 \%$ of married women have experienced physical violence committed by their current husbands during their lifetime, and approximately $50 \%$ of married women experienced such violence in the past 12 months, which implies that the recent incidence is also high (BBS, 2013). This report claims that the prevalence of physical violence seems comparatively higher in rural Bangladesh than urban areas, with the women of 20-39 age group being the most exposed in cases of physical violence in the past 12 months (BBS, 2013). This report also claims that more than $50 \%$ of women received medical treatment as a result of physical violence, though the rest did not seek medical treatment due to the fear of their husbands or not being permitted to do so by their husbands, as well as the fear of stigma also preventing them from seeking medical treatment. On the other hand, a portion of women cited that 'social prestige' as a reason for not having sought medical treatment (BBS, 2013). The dowry practice has been acting as an influential factor in the physical oppression against married women in Bangladesh, with in-laws also sometimes participating in these acts with the husbands.

Economic and social oppression: The contemporary forms of dowry practices are typically distinguished by the high levels of payment involved, the fact that the amount to be given is integral to marriage negotiations and the fact that the transfer goes directly to the groom or his family (White, 2017). It is noted, "how the consumer goods transferred symbolized modern masculinity, with the motorbike as an emblematic example. Materially, dowries have now become increasingly central to young men's ability to establish themselves in the modern economy, providing capital for business or the cash or connections required for career advancement, including through international migration' (White, 2017). So, this economic transferring from the bride's side to the groom's side itself is economic oppression against women. In the same way, because of the settlement of dowry payments just before the marriage, the 
marriage may stopped, which hinder the prestige of women and her family. In contrast, after a marriage, the endless demands of the dowry may come out of the divorce settlement, which is also another form of social oppression towards women and their parent's family. The social and economic costs of psychological, sexual and physical oppression against women are also huge, according to social science and public health researchers attempting to explain this in the contemporary world. The Violence against Women Survey in 2011 reports that approximately half of all married women have experienced economic violence, and approximately one-third of women (33.7\%) have paid a dowry in their current marriage (BBS, 2013).

Dowry deaths of married women: In Bangladesh, violence against women due to dowry practices has been taking a variety of forms, including dowry deaths, the killing of women or forcing women into suicide, with the international organizations and researchers calling these deaths a form of 'femicide'. The researchers agreed that because of dowry practices in Bangladesh women are being harassed, harmed or killed, including women being burned to death, and deaths of women labeled as suicides. As referred to above, the quantitative data and information on the dowry deaths of women are still scarce and not well documented. The legal process to proving a dowry death is also an obstacle before any verdict comes from a court. Nevertheless, human rights organizations that are working in Bangladesh to collect data on dowry deaths from national newspapers in an attempt to document them. Among the human rights organizations that collect and document dowry deaths or dowry killing data, Ain o Salish Kendra - ASK (A Legal Aid and Human Rights Organization in Bangladesh) and Odhikar (A Human Rights organization in Bangladesh) are pioneers. The data that the organizations collect are also the incidences which are reported in newspapers. Tables 1 and 2 cite the situation in Bangladesh. 
Table 1: Dowry deaths of women from 2001 to 2017 in Bangladesh

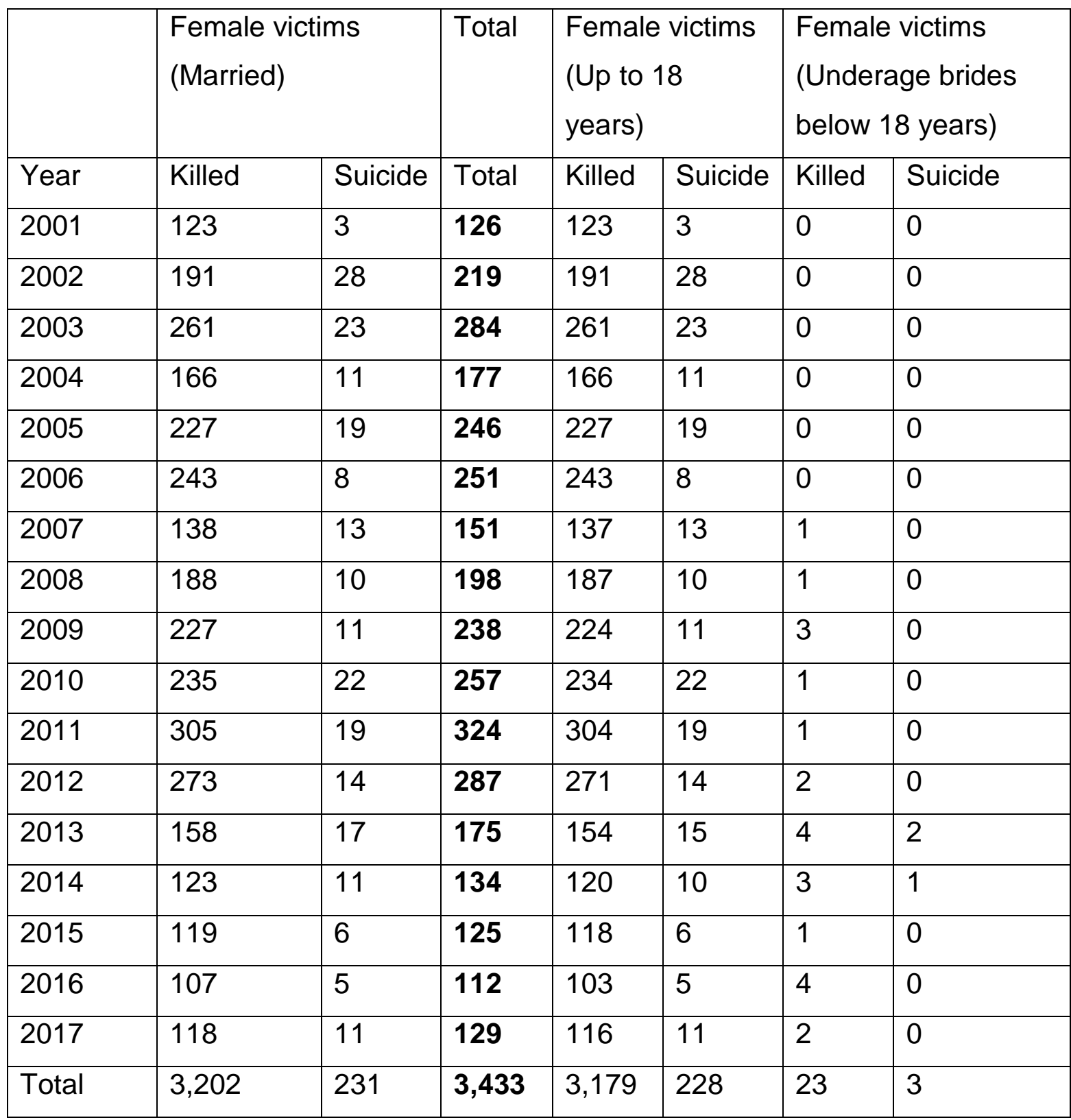

Source: Redrawn from Odhikar's Statistics on Violence against Women (Dowry-related violence against women from 2001-2017)

Table 1 revealed that 3,202 married women were killed and 231 married women died by suicide during the aforementioned period because of dowries. The average number of dowry deaths of women is more than 201 women every year. 
Table 2: Dowry deaths from 2014 to 2017 with age distribution and case files

\begin{tabular}{|c|c|c|c|c|c|c|c|c|}
\hline \multirow[t]{2}{*}{ Year } & \multirow[t]{2}{*}{ Categories of death } & \multicolumn{4}{|c|}{ Age limit } & \multirow{2}{*}{$\begin{array}{l}\text { Not } \\
\text { mentioned }\end{array}$} & \multirow[t]{2}{*}{ Total } & \multirow{2}{*}{$\begin{array}{l}\text { Case } \\
\text { filed }\end{array}$} \\
\hline & & $\begin{array}{l}13- \\
18\end{array}$ & $\begin{array}{l}19- \\
24\end{array}$ & $\begin{array}{l}25- \\
30\end{array}$ & $30+$ & & & \\
\hline \multirow[t]{3}{*}{2014} & Death after physical torture & 12 & 51 & 39 & 11 & 50 & 163 & 90 \\
\hline & Suicide after torture & 0 & 6 & 0 & 0 & 5 & 11 & 1 \\
\hline & Sub total & 12 & 57 & 39 & 11 & 55 & 174 & 91 \\
\hline \multirow[t]{3}{*}{2015} & Death after physical torture & 12 & 62 & 48 & 10 & 55 & 187 & 99 \\
\hline & Suicide after torture & 1 & 7 & 1 & 1 & 0 & 10 & 3 \\
\hline & Sub total & 13 & 69 & 49 & 11 & 55 & 197 & 102 \\
\hline \multirow[t]{3}{*}{2016} & Death after physical torture & 7 & 45 & 22 & 10 & 42 & 126 & 61 \\
\hline & Suicide after torture & 0 & 2 & 2 & 0 & 0 & 4 & 0 \\
\hline & Sub Total & 7 & 47 & 24 & 10 & 42 & 128 & 61 \\
\hline \multirow[t]{3}{*}{2017} & Death after physical torture & 16 & 60 & 31 & 7 & 33 & 245 & 96 \\
\hline & suicide after torture & 0 & 3 & 3 & 0 & 4 & 6 & 4 \\
\hline & Sub total & 16 & 63 & 34 & 7 & 37 & 251 & 100 \\
\hline
\end{tabular}

Source: Redrawn from Ain O Salish Kendra (ASK) Human Rights Monitoring data on Violence against Women - Dowry, 2014-2017

Table 2 shows dowry-related deaths for four consecutive recent years in Bangladesh. There are two types of deaths depicted in this table. These are suicides after torture and deaths after physical torture in the different age groups. The total amount of deaths is 750 women in four years, with the average number of deaths from dowries being 187 women per year. The death incidents from dowries vary in the different age groups. In this timeframe, 354 cases were filed against the 750 deaths.

'Why are dowry deaths call femicide'? Every year, a number of women and girls are killed or forced to commit suicide because of dowry practices in Bangladesh, as observed in Table 1 and 2. The WHO (2012) states that 'femicide is generally understood to involve the intentional murder of women because they are women, but broader definitions include any killings of women or girls'. 'Femicide' was originally defined as the killing of women, but has been adapted over time to represent the act of killing women because of their gender (AUCAS, 2013). The Vienna Declaration on Femicide from 2012 has also recognized the dowry-related killing of women and girls as one of the forms of femicide (AUCAS, 2013). Femicide is usually perpetrated by men, but sometimes female family members may also be involved. Most dowry deaths in Bangladesh are caused by the husbands of the women and girls, though sometimes 
other family members, especially in-laws, are also involved. The murders or dowryrelated deaths mostly happen in the groom's home by husbands along with other family members. As a result, the researchers and international organizations counted these deaths as a form of femicide. Following this, dowry-related deaths in Bangladesh are identified as one form of femicide.

\section{CONCLUSION}

The practice of the dowry system has deep cultural roots in all parts of the world, going back to ancient Greek city-states and Roman times, and also in ancient India. But the contemporary practice of dowry in Bangladesh emerged in the 20th century as the process of the masculinization of the economy, as well as the liberalization of markets. Before that, the bride-wealth marriage system was practiced in Bangladesh society and the present form of dowry was absent. The contemporary practice of dowry is the opposite of bridewealth marriage. The researchers and scholars support different theories in explaining the problem in Bangladesh, as well as the Indian sub-continent. These theoretical explanations are very important to understand the practice of dowry, as every theory has some implications for understanding the problem more deeply. It is noted that the relationships of power pervade dowry practices. The reality is that nowadays dowry is commonly used as a tool of resource extraction and exploitation of the bride and her natal family. Within the backdrop of patriarchy, dowry, with its economic potential, provides husbands with an incentive to divorce, abandon, abuse and even kill their wives. Thus, dowry, a product of patriarchy, represents patriarchy and is linked to violence. Psychological, sexual, physical, socio-economic and many other forms of domestic violence occur because of the dowry practice, ultimately turning into femicide in Bangladesh. Although the dowry practice in Bangladesh is legally banned and a criminal offence, it is still a widespread practice all over the country. Every year, a number of women and girls lose their lives from these dowryrelated deaths. The number of dowry-related deaths of women and girls is alarming. But solid data on dowry-related issues, especially quantitative data on dowry deaths, is fairly rare; thus, more systematic data collection and documentation is needed. 


\section{References}

Agarwal, B. (1994). A Field of One's Own - Gender and Land Rights in South Asia, Cambridge: Cambridge University Press.

Ain o Salish Kendra - ASK (2018). [A Legal Aid and Human Rights Organization in Bangladesh], website: http://www.askbd.org/ask/category/hrmonitoring/violence-against-women-statistics/dowry-related-violence/page/12/ (access date: 13 February 2018).

Ameen, N. (1997). 'Dowry in Bangladesh: How many more Deaths to its End?' The Dhaka University Studies, Part F, vol. VIII, no. 1, pp. 125-155.

Amin, S., \& Cain, M. T. (1997). "The rise of dowry in Bangladesh," in The Continuing Demographic Transition, G. W. Jones et al. (Eds.), Oxford, England: Clarendon Press, pp. 290-306.

Amin, S., Selim, N., \& Waiz, N. K. (2006). Causes and consequences of early marriage in Bangladesh: Background report for workshop on programs and policies to prevent early marriage. Dhaka: Population Council.

Amin, S., \& Suran, L. (2005). The impact of marriage payment on leisure, housework and abuse of young wives: Some evidence from rural Bangladesh. Paper presented at the Annual Meeting of the Population Association of America, Philadelphia.

AUCAS (2013). Femicide: A Global Issue That Demands Action, Claire Laurent, Michael Platzer and Maria Idomir et al., the Academic Council on the United Nations System (ACUNS) Vienna Liaison Office.

Banerjee, K. (1999). 'Gender Stratification and the Contemporary Marriage Market in India', Journal of Family Issues, Sept. 1999, 20(5), pp. 648-676.

BBS (2013). Violence Against Women Survey 2011. Dhaka, Bangladesh:

Bangladesh Bureau of Statistics-BBS, Ministry of Planning, Government of the People's Republic of Bangladesh.

Begum, A. (2014). 'Dowry in Bangladesh: A search from an international perspective for an effective legal approach to mitigate women's experiences. Journal of International Women's Studies, 15(2), pp. 249-267.

Bhat, P. N., Halli, M., \& Halli, S. S. (1999). "Demography of brideprice and dowry: Causes and consequences of the Indian marriage squeeze," Population Studies, 53(2): pp. 129-148. 
Brown, P. (2002). Dowry and intra-household bargaining: Evidence from China (Working paper no. 608). William Davidson Institute, Michigan Business School.

Caldwell, J.C., Reddy, P., \& Caldwell, P. (1983). "The causes of marriage change in South India," Population Studies, 37: pp. 343-361.

Chowdhury, F. D. (2010). 'Dowry, Women, and Law in Bangladesh' International Journal of Law, Policy and the Family 24(2), pp. 198-221.

Geirbo, H. C., \& Imam, N. (2006). "The Motivation Behind Giving and Taking Dowry". Research Monograph Series No. 28, BRAC, Research and Evaluation Division.

Hartmann, B., \& Boyce, J. (1983). A Quiet Violence: View from a Bangladesh Village, London: Zed Press.

Hossain, K. T. (2007). 'Violence against Women in Bangladesh', in the Proceedings of the 8th Annual Conference of Hong Kong Sociological Association, C. S. Keung, H. Traver \& L. Xiuguo (Eds.), Narratives and Perspectives in Sociology: Understanding the Past, Envisaging the Future. pp. 257-264.

Huda, S. (2006). 'Dowry in Bangladesh: Compromising Women's Rights," South Asia Research, 26(2006), pp. 249-268.

Jahan, R. (1994). 'Hidden Danger: Women and Family Violence in Bangladesh, Dhaka: Women for Women.

Johnston, H. B., \& Naved, R. T. (2008). 'Spousal Violence in Bangladesh: A Call for a Public-health Response', J Health Popul Nutr, 26(3), pp. 366-377.

Kamruzzaman, M., \& Rahman, A. M. (2009). 'Dowry related violence against women in Bangladesh', Empowerment, Journal of Women for Women.

Kamruzzaman, M. (2015). 'Dowry Related Violence Against Rural Women in Bangladesh, American Journal of Psychology and Cognitive Science, 1(4), 2015, pp. $112-116$

Kishwar, M. (2002). Off the beaten track - rethinking gender justice for Indian women. New Delhi: Oxford University Press.

Lindenbaum, S. (1981). 'Implications for women of changing marriage transactions in Bangladesh'. Studies in Family Planning, 12, pp. 394-401.

Monsoor, T. (2003). 'Dower and dowry: Its affect on the empowerment of Muslim women', Star Law Analysis, The Daily Star, July 27. 
Monsoor, T. (2003). 'Dowry Problem in Bangladesh: Legal and Socio-Cultural Perspectives', The Dhaka University Studies, Part-F, vol. XIV, no. 1, pp.1-16. Monsoor, T. (2008). Gender Equity and Economic Empowerment: Family Law and Women in Bangladesh, Dhaka, Bangladesh: British Council.

Naved, R. T., \& Persson, L. A. (2010). 'Dowry and Spousal Physical Violence Against Women in Bangladesh', Journal of Family Issues $X X(X)$, Sage Publication, pp. 1-27.

Nithya, N. R. (2013) 'Institutionalization of Dowry in India: Social Custom or Modern Malaise?' International Journal of Science and Research (IJSR), India Online, Volume 2 Issue 9, September 2013, www.ijsr.net, visited on 9 September 2017.

Odhikar (2018) [A human Rights Organization in Bangladesh], website: http://odhikar.org. http://odhikar.org/statistics/statistics-on-violence-againstwomen/ (access date: 14 February 2018).

Oldenburg, V. T. (2002). Dowry murder - the imperial origins of a cultural crime. New Delhi: Oxford University Press.

Rahman, S., \& Khanam, W. (2008). 'Violence Against Women in Bangladesh: A Sociological Analysis', in seminar volume on: Globalization, Patriarchy and Women Oppression: Bangladesh perspective, In S. Rahman \& W. Khanam (Eds.), FWCA Rajshahi, pp. 38-51.

Rao, V. (1993). "Dowry 'inflation' in rural India: A statistical investigation”, Population Studies, 47(2): pp. 283-293.

Risley, H. (1915). The people of India. Delhi, India: Oriental Books.

Roy, R. D. (1992). 'Battered Spouse Syndrome: Violence against Women in Marriage', Dhaka: Research and Evaluation Division, BRAC.

Rozario, S. (2001). Purity and communal boundaries: Women and social change in a Bangladeshi village. Dhaka: The University Press Limited.

Schuler, S. R., Hashemi, S. M., \& Badal, S. H. (1998). 'Man's Violence against Women in Bangladesh: Undermined or Exacerbated by Microcredit Programmes?' Development in Practice, 8(2), pp. 148-157.

Sharma, U. (1980). Women, work and property in North-West India. London: Tavistock.

Siddiqi, D. M. (2002). 'Dowry: Ancient custom or modern malaise?' Dhaka: The Daily Star, 19 February 2002. 
Srinivas, M. N. (1984). Some Reflections on Dowry, Delhi: Oxford University Press. Suran, L., Amin, S., Huq, L., \& Chowdury, K. (2004). Does Dowry Improve Life for Brides? A Test of the Bequest Theory of Dowry in Rural Bangladesh, The Population Council, Inc.

Taher, M. A, Islam, M. R., Chowdhury, M. A. M., \& Siddiqua, S. (2014). 'Combating Dowry Violence against Women in Bangladesh: A Critical Study' International Journal of Innovation and Applied Studies, 8(3), pp. 1126-1131.

UNECE (2010). Interviewer's manual: Violence against Women Survey using the UNECE VAW Module. Retrieved July 23, 2014 from the United Nations Economic Commission for Europe: http://www1.unece.org/stat/platform/download/attachments/24117336/VAW+ module+Intervi ewer\%27s+Manual+\%282+March+2011\%29.doc?version=1

White, S. C. (1992). Arguing with the crocodile: Class and gender hierarchies in a Bangladeshi village. Dhaka: University Press Limited.

White, S. C. (2017). 'Patriarchal Investments: Marriage, Dowry and the Political Economy of Development in Bangladesh', Journal of Contemporary Asia, 47(2), pp: 247-272.

WHO (2012). Understanding and addressing violence against women, http://www.who.int/about/licensing/copyright_form/en/index.html). Downloaded, 20.09.2017.

Zaman, H. (1999). 'Violence against Women in Bangladesh: Issues and Responses', Women's Studies International Forum, 22(1): pp. 37-48. 